\title{
STUDIES ON THE BREEDING SYSTEM OF THE FIELD BEAN, VICIA FABA (L.)
}

\author{
J. H. W. HOLDEN and D. A. BOND* \\ Department of Agricultural Botany, King's College, \\ University of Durham
}

Received I4.iii.6o

\section{NATURAL CROSS BREEDING IN V. FABA}

THE failure of plant breeders to produce new varieties which show any real improvement in yield and reliability over established strains puts the field bean in an unique position among the important farm crops and has probably been at least partly responsible for the steady decline in acreage of this potentially valuable source of concentrated protein.

This lack of improved varieties must be attributed to unsatisfactory breeding techniques and these in turn to an imperfect understanding of the breeding system. In order therefore to gain more information on the breeding system of $V$. faba, the experiments to be described here were conducted at the University Experimental Farm, Cockle Park, Northumberland using winter varieties of $V$. faba equina and spring varieties of $V$. faba minor and $V$. faba major.

The first step in our study of the breeding system was to estimate the frequency of cross fertilisation. Various workers have made such estimates. In this country Fyfe and Bailey (I95I) and Fyfe (I954) estimated $3 \mathrm{I} \cdot 2,48 \cdot 5,26 \cdot \mathrm{I}$ and $36 \cdot 2$ per cent. cross fertilisation for winter beans grown in I948 to I95 I respectively. Griffiths and Rowlands (unpublished) working with winter and spring beans have obtained estimates ranging from 25 to $5^{\circ}$ per cent. cross fertilisation. In Europe, and for spring beans, Sirks (I923) estimated 34, 4I, 3 I, 25 and 38 per cent. for the years I9I8-22, Crebert (I93I) 5-8 per cent., Picard (I953) using over 40 samples collected from different parts of France and Germany produced estimates ranging from I 9 to 79 per cent., while Shen (I 947) in Szechuan estimated 24 per cent. crossbreeding. Some of the continental estimates are close to those obtained in this country, while others vary widely. The occurrence of this variation is not perhaps surprising when one considers that they relate to different material grown under differing climatic conditions which will not only affect the plant but also the insect pollinators and their activity. Thus, estimates made on continental populations may bear little relationship to the situation in this country. Picard (I953) for example, noted a relationship between the origin of his samples and the amount of natural crossing, the lower values occurring in stocks grown on the western seaboard of France, and the higher values from eastern France and from Germany.

* Now at the Plant Breeding Institute, Cambridge. 


\section{(i) Winter beans}

(i) Material and Methods. Colour of the seed hilum is a useful character for the detection of cross fertilisation and has been used in this work. It is generally recognised that hilum colour shows monofactorial inheritance (Sirks, I931 ; Erith, I930 ; Picard, I953; and Fyfe and Bailey, 1951) with black dominant over colourless. Two tests show that the same simple situation exists in this material.

(a) Seeds of $F_{1}$ hybrids between black and colourless hilum plants were black in colour. When selfed these $F_{1}$ 's yielded progeny in the ratio of 22 black : 8 colourless. $\chi^{2}$ for fit to expected $3:$ i ratio $=0.044 . \quad P>0.8$.

(b) Heterozygotes which were open pollinated in a population estimated to contain the two alleles in equal frequencies yielded 510 black and 164 colourless hilum progeny. $\chi^{2}$ for a fit to expected $3: \mathrm{I}$ ratio $=0 \cdot 179$. $\mathrm{P}>0 \cdot 5$.

Sampling. Winter bean material was obtained from two sources :

(a) A random sample of 332 plants was taken immediately prior to harvest from plots of a number of different stocks at Cockle Park. These plants were scored for hilum colour and other characters.

(b) A random sample of II 5 plants was taken from a Norfolk crop, and later, six samples of not less than I 50 seeds were taken from the threshed produce of the same crop. Both plants and seeds were scored for hilum colour.

Planting 1954. Cockle Park parents. Progenies of 37 white hilum plants and 36 black hilum plants were sown in alternate progeny rows, with 25 plants per row.

Norfolk parents. Progenies of 14 white hilum plants and 15 black hilum plants were sown in the same way.

Planting 1955 . Two or three plants were taken from 36 of the 1954 rows but no selections were made from rows which were the progeny of 1953 heterozygotes. Ninety-nine selections were taken in this way and their progeny again sown in progeny rows, 25 plants per row, in 1955. A diagrammatic representation of the method of sowing and scoring the material is given in fig. $\mathbf{I}$.

Estimations were made in 1954 of crossing in natural populations in I953, and in 1955 of crossing in artificial populations in 1954. In each year the general procedure was to estimate,

(a) the amount of cross fertilisation due to pollen carrying the dominant allele.

(b) the frequency of the dominant allele in the parent population and thence

(c) the total amount of cross fertilisation.

Using Fyfe and Bailey's (I95I) notation, if $n_{3}$ is the total number of progeny plants scored from homozygous recessive mothers, if $l$ is the number of black hilum plants in that progeny and if $p$ is the frequency of the dominant allele in the parent population, then the estimated frequency of cross fertilisation is derived from $\frac{1}{n_{3}} \times \frac{1}{p}$.

The estimation of $p$. (a) The 1953 populations were natural field populations. We make the assumption that these populations were in equilibrium and the Hardy-Weinberg rule was used to determine the frequency of $p$. Hence the frequency of $\mathcal{N}=p=\mathbf{I}-\sqrt{\text { frequency of } n n}$. In the case of the Norfolk population the frequency of $n n$ genotypes was derived from the seed sample data and its attached error (see table 2) is the standard error of the mean of six sub-samples. For the Cockle Park population the estimate is derived from the number of white hilum plants in the original random sample and its attached error is the standard deviation of the proportion of $n n$ genotypes in the sample from $s=\sqrt{\frac{p q}{n}}$

Some support for the use of the Hardy-Weinberg rule comes from a recalculation of $p$ using the proportions of homozygotes to heterozygotes in the 1954 progeny of the 36 black hilum plants (fig. I) to estimate the frequency of $\mathcal{N N}: \mathcal{N} n$ in the I953 
population as 0.267 and 0.534 respectively. Hence $\mathcal{N}=p=0.267+\frac{0.534}{2}=0.534$ which is very close to the value of 0.554 obtained by Hardy-Weinberg. However, it must be borne in mind, that this second estimate is derived from a very small sub-sample of the population.

\section{COCKLE PARK}

NORFOLK

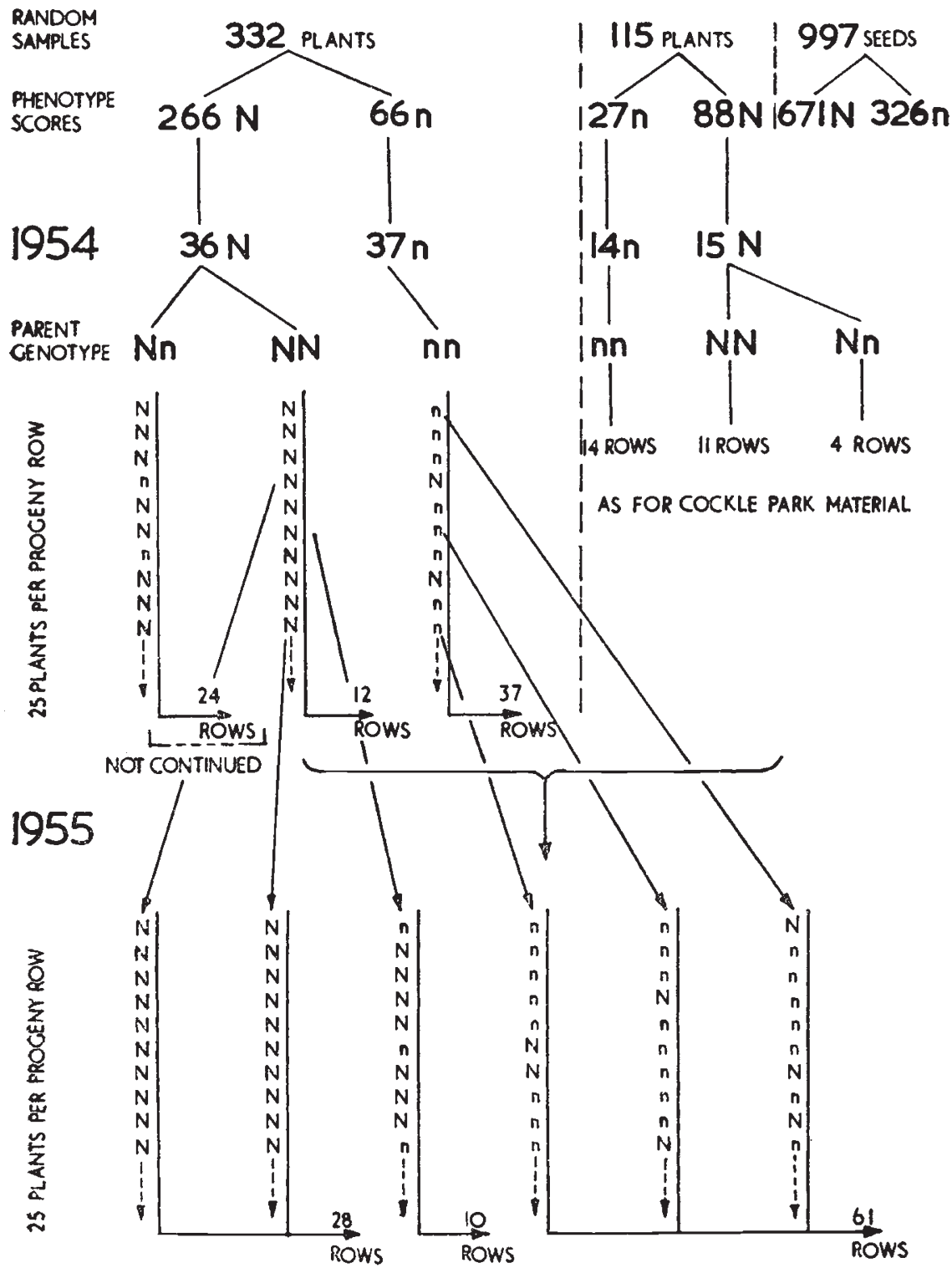

FIG. 1-Diagrammatic representation of sampling and planting procedures for winter beans.

Note:- I 955 sowings made from progeny of I 953 homozygotes only, and only "colourless" selected from progenies of "colourless". 
(b) The 1954 population consisted of the systematic plantings of equal numbers of progenies of black and colourless hilum plants drawn from the field populations, (see fig. I). Hence the parents of the 1954 population were not drawn at random with respect to the alleles $\mathcal{N}$ and $n$ and therefore use of the Hardy-Weinberg rule for the estimation of $p$ was out of the question.

However, it was possible to arrive at a value for $p$ from estimates of the numbers of plants of the three genotypes which were present in 1954 .

TABLE I

Genotypic frequencies in 1954 population of winter beans

\begin{tabular}{|c|c|c|c|c|c|c|}
\hline \multirow{2}{*}{$\begin{array}{l}\text { Genotype } \\
\quad \text { I953 }\end{array}$} & \multirow{2}{*}{$\begin{array}{l}\text { Genotype } \\
1954\end{array}$} & \multicolumn{2}{|c|}{ No. of plants } & \multicolumn{3}{|c|}{$\begin{array}{l}\text { Proportion of } 1954 \text { population } \\
\text { with genotype }\end{array}$} \\
\hline & & Observed & Estimated & $\mathcal{N N}$ & $\mathcal{N} n$ & $n n$ \\
\hline \multirow{2}{*}{$\mathcal{N N}$} & $\mathcal{N N}$ & \multirow{2}{*}{539} & 397 & 0.1645 & $\cdots$ & $\ldots$ \\
\hline & $\mathcal{N} n$ & & $14^{2}$ & $\ldots$ & 0.0588 & $\ldots$ \\
\hline \multirow{3}{*}{$\mathcal{N} n$} & $\mathcal{N N}$ & \multirow{2}{*}{510} & I 73 & 0.0717 & $\ldots$ & $\ldots$ \\
\hline & $\mathcal{N} n$ & & 337 & $\ldots$ & $0 \cdot 1396$ & $\ldots$ \\
\hline & $n n$ & I 64 & $\ldots$ & $\ldots$ & $\ldots$ & 0.0679 \\
\hline \multirow{2}{*}{$n n$} & $\mathcal{N} n$ & 210 & $\ldots$ & $\ldots$ & 0.0870 & $\ldots$ \\
\hline & $n n$ & $99^{I}$ & $\ldots$ & $\ldots$ & $\ldots$ & 0.4105 \\
\hline Total & & $24^{14}$ & I049 & 0.2362 & 0.2854 & $0.47^{8} 4$ \\
\hline \multicolumn{7}{|c|}{ Hence the frequency of $\mathcal{N}=p=0.2362+\frac{0.2854}{2}=0.3789$} \\
\hline
\end{tabular}

The genotypic frequencies for this population are given in table I, and the methods for deriving the estimated values were as follows. In the I954 sowings, some 23 progeny rows were homogeneous for black hilum colour (see fig. I). In order to estimate the number of heterozygotes among the 539 plants in this group, three plants were taken at random from each of $\mathrm{I} 3$ of these progenies and grown on in 1955 as progeny rows again (see fig. 1 ). Ten out of a total of 38 segregated for hilum colour; the remainder bred true to black hilum. This ratio of $0.7368 \mathcal{N N}$ to $0.2632 \mathcal{N} n$ was used as an estimate of the frequency of homozygotes and heterozygotes in the 1954 " all black" rows.

The other case where 1954 genotypic frequencies could not be scored directly from the 1955 progenies concerns the frequencies of homozygous and heterozygous blacks in the 1954 segregating progenies. These progenies were derived from heterozygotes which had undergone both selfing and crossing. From each type of mating we can expect 50 per cent. of the progeny to be heterozygotes again, the number of homozygous recessives is determined by observation and therefore the number of homozygous blacks may be estimated by subtraction of the sum of the other two types from the total. 
(ii) Results. The hilum colour scores of the 1954 and 1955 progenies of the 1953 and 1954 populations respectively, are given in table 2, together with the estimates of $p$, and of the percentage cross fertilisation.

The estimates of cross fertilisation for the two I953 populations are reasonably close to each other, and are in marked contrast to the

TABLE 2

Parent and progeny data on hilum colour, with estimates of cross fertilisation in winter beans, 1953 and 1954

\begin{tabular}{|c|c|c|c|c|c|c|c|c|c|}
\hline \multirow{2}{*}{ Population } & \multicolumn{2}{|c|}{ Estimates of } & \multirow{2}{*}{$\begin{array}{l}\text { Parent } \\
\text { pheno- } \\
\text { type }\end{array}$} & \multirow{2}{*}{$\begin{array}{c}\text { Parent } \\
\text { genotype }\end{array}$} & \multirow{2}{*}{$\begin{array}{c}\text { No. of } \\
\text { progenies }\end{array}$} & \multicolumn{3}{|c|}{$\begin{array}{l}\text { No. of plants } \\
\text { with hilum }\end{array}$} & \multirow{2}{*}{$\begin{array}{c}\text { Cross } \\
\text { fertilis- } \\
\text { ation } \\
\text { per cent. }\end{array}$} \\
\hline & $\begin{array}{l}\text { " } n n \text { " plants } \\
\text { in parent } \\
\text { population }\end{array}$ & $p$ & & & & Black & $\begin{array}{l}\text { Colour- } \\
\text { less }\end{array}$ & Total & \\
\hline $\begin{array}{l}\text { I953 } \\
\text { Norfolk }\end{array}$ & $0.327 \pm 0 \cdot 01$ & 0.428 & $\begin{array}{l}\text { Black } \\
\text { Black } \\
\text { C'less }\end{array}$ & $\begin{array}{l}\mathcal{N N} \\
\mathcal{N} n \\
n n\end{array}$ & $\begin{array}{r}\text { I I } \\
4 \\
\text { I } 4\end{array}$ & $\begin{array}{r}253 \\
70 \\
4^{I}\end{array}$ & $\begin{array}{r}0 \\
28 \\
284\end{array}$ & $\begin{array}{r}253 \\
98 \\
325\end{array}$ & $29 \cdot 49$ \\
\hline Cockle Park & $0.199 \pm 0.02$ & 0.554 & $\begin{array}{l}\text { Black } \\
\text { Black } \\
\text { C'less }\end{array}$ & $\begin{array}{l}\mathcal{N N} \\
\mathcal{N n} \\
n n\end{array}$ & $\begin{array}{l}12 \\
24 \\
37\end{array}$ & $\begin{array}{l}286 \\
440 \\
169\end{array}$ & $\begin{array}{r}0 \\
136 \\
707\end{array}$ & $\begin{array}{l}286 \\
576 \\
876\end{array}$ & $34 \cdot 8 \mathrm{I}$ \\
\hline I954 Cockle Park & $\cdots$ & 0.379 & $\begin{array}{l}\text { Black } \\
\text { Black } \\
\text { C'less }\end{array}$ & $\begin{array}{l}\mathcal{N N} \\
\mathcal{N} n \\
n n\end{array}$ & $\begin{array}{l}28 \\
\text { IO } \\
6 \mathrm{I}\end{array}$ & $\begin{array}{l}790 \\
187 \\
432\end{array}$ & $\begin{array}{r}0 \\
77 \\
1200\end{array}$ & $\begin{array}{r}790 \\
264 \\
1632\end{array}$ & $69 \cdot 84$ \\
\hline
\end{tabular}

value of 70 per cent. estimated for the I954 population, which approaches the very high values obtained by Picard (I953).

\section{(ii) Spring beans}

(i) Material and Methods. Two marker genes were used to estimate natural crossing in the spring bean material, one affecting seed coat colour, the other plant height.

Erith (1930) showed that each of these characters is controlled by a single major gene. This is confirmed by observations made during the course of this work on segregating $F_{2}$ progenies from selfed $F_{1}$ 's derived from controlled hybridisations, and on the progeny of open pollinated homozygous lines. These observations reveal the dominance relationships to be as follows :-

(a) buff testa dominant to yellow testa ( $V$. faba minor).

(b) buff testa dominant to green testa dominant to red testa ( $V$. faba major).

(c) tall habit dominant to dwarf habit ( $V$. faba major).

Estimations were made from 1955 progenies of the amount of natural crossing on parents in systematic plantings in 1954 . 
Planting. Three experimental plots were sown in 1954 as follows :-

(a) a yellow seeded German " minor" variety, "Goldbohne" was planted systematically with buff-seeded English " Tic" beans.

(b) rows of buff testa garden broad beans alternating with rows of red testa broad beans.

(c) rows of dwarf buff seeded broad beans alternating with rows of tall green seeded broad beans.

Three plants were taken at random from each of the homozygous recessive tester rows-except the three rows at both ends of each plot-and their progeny grown on in 1955 and scored for the presence of the dominant allele, giving a measure of the amount of cross fertilisation due to the dominant allele as $\frac{l}{n_{3}}$.

TABLE 3

Estimates of cross fertilisation in spring varieties of $\mathrm{V}$. faba minor and V. faba major, 1954

\begin{tabular}{|c|c|c|c|c|c|c|c|}
\hline \multirow{2}{*}{ Parent plants } & \multirow{2}{*}{$\begin{array}{c}\text { No. of } \\
\text { progenies } \\
\text { I955 }\end{array}$} & \multicolumn{3}{|c|}{$\begin{array}{l}\text { Progeny scores of } \\
\text { recessive " testers" } \\
\text { No. of individuals carrying }\end{array}$} & \multirow{2}{*}{$\begin{array}{l}\text { Frequency } \\
\text { of cross } \\
\text { fertilisa- } \\
\text { tion due to } \\
\text { dominant } \\
\text { allele }\end{array}$} & \multirow{2}{*}{$\begin{array}{c}\text { Estimate } \\
\text { of } p\end{array}$} & \multirow{2}{*}{$\begin{array}{l}\text { Estimated } \\
\text { percentage } \\
\text { cross } \\
\text { fertilisa- } \\
\text { tion }\end{array}$} \\
\hline & & $\underset{\text { dominant }}{\text { allele }}$ & $\begin{array}{c}\text { recessive } \\
\text { alleles }\end{array}$ & Total & & & \\
\hline $\begin{array}{l}V . \text { faba minor } \\
\text { Goldbohne } \times \\
\text { Tic }\end{array}$ & 99 & 862 & I3I4 & 2176 & $0 \cdot 396$ & $0 \cdot 66$ & $60 \cdot 46$ \\
\hline $\begin{array}{c}\text { V. faba major } \\
\text { Red Testa } \times \\
\text { Buff Testa }\end{array}$ & 9 & 44 & I 34 & I 78 & 0.247 & $0 \cdot 76$ & $32 \cdot 55$ \\
\hline $\begin{array}{l}\text { Dwarf Habit } \\
\times \text { Tall Habit }\end{array}$ & 9 & 23 & 59 & 82 & $0 \cdot 28 \mathrm{I}$ & $0 \cdot 80$ & $35 \cdot 06$ \\
\hline $\begin{array}{l}\text { Green Testa } \\
\times \text { Buff Testa }\end{array}$ & 9 & 33 & I 34 & 167 & $o \cdot 19^{8}$ & 0.48 & $41 \cdot 17$ \\
\hline
\end{tabular}

Estimation of $p$. The estimation of the frequency of the dominant allele, as $p$, is simpler than in the case of the winter beans. An examination of seed size in progenies indicated an absence of fertilisation between the broad beans and the small seeded " minor" varieties. Erith (1930) showed that such hybrid seeds were intermediate in size and distinguishable from either parent. Therefore each subspecies was treated as a separate population even though they were grown in the same field.

All samples sown were homogeneous and all parent individuals grown and scored proved to be homozygous.

The value of $p$ was therefore estimated directly from the known number of plants of the two genotypes within each area. In the case of the broad bean population all plants with testa colours other than red carried the allele dominant to red, hence $p$ in the red and buff testa estimates included the frequency of the green allele, and in the green and buff testa planting the frequency of the red allele was taken into account as a component of $q$ (the recessive allele) since "green " $\times$ " red" matings were not scorable in $F_{1}$. 
(ii) Results. The phenotype scores of the progenies of the recessive testers are given in table 3 together with estimates of the dominant gene frequencies and of the percentage cross fertilisation in the four experiments.

The amount of cross fertilisation in the "minor" varieties is of the same order as that in the "equina" or winter bean varieties in the same year. There is, however, a notable reduction in outcrossing on the broad bean varieties.

\section{(iii) Plant density and cross fertilisation}

A small trial sown with spring beans in 1955 was designed to determine whether variations in plant density had some bearing on

\section{TABLE 4}

Estimates of percentage cross fertilisation at two densities of planting $\mathrm{V}$. faba major

\begin{tabular}{|c|c|c|c|c|c|}
\hline $\begin{array}{c}\text { Spacing of } \\
\text { parent plants }\end{array}$ & $\begin{array}{c}\text { Progeny of red testa } \\
\text { parents with }\end{array}$ & $\begin{array}{c}\text { Frequency of } \\
\text { buff testa } \\
\text { hybrids }\end{array}$ & $\begin{array}{c}\text { Estimated } \\
\text { frequency of } \\
\text { buff allele } p\end{array}$ & $\begin{array}{c}\text { Estimate of } \\
\text { percentage } \\
\text { cross } \\
\text { fertilisation }\end{array}$ \\
\hline Low density. & 35 & 40 & 0.533 & -0.816 & 65.31 \\
High density . & 45 & 23 & $0.33^{2}$ & 0.809 & 41.78 \\
\hline
\end{tabular}

Expecting no effect due to density $\chi^{2}=5.574 \quad \mathrm{P}=<0.025$.

the large difference between the percentages of cross fertilisation in I 953 and I954.

The red testa and buff testa varieties of broad bean were planted systematically, such that each homozygous recessive red was surrounded by homozygous dominant buffs. Two densities of planting were used,

(a) plants $2 \mathrm{ft}$. apart each way-Low density.

(b) plants 6 in. apart each way-High density.

The seed progeny of the red testa testers was bulked within each density group, and the two bulks grown on in the following season and scored for testa colour. The results are given in table 4 .

These results give some confirmation that plant density can influence the frequency of cross fertilisation and indicate that at high density this will be reduced, probably through reduced access to flowers hindering bee visitation. This conflicts with Fyfe's (I 954) conclusion that cross fertilisation was greater at higher plant densities. 


\section{THE CONTROL OF THE BREEDING SYSTEM}

Tripping may be defined as the release of the stigma and style from the enveloping keel petals. Careful dissection of flowers shows that the stigmatic papillæ are ruptured by the tripping process, as reported by Rowlands (1958) in $V . f a b a$ and by Armstrong and White (I935) in alfalfa. The dissections also showed that pollen is present in the keel and on the stigma for some 24 hours before the flower is open and ready for bee visitation. Since the majority of the estimates of percentage self-fertilisation are grouped about 70 per cent. it is clear that this self-pollination does not lead to complete self-fertilisation. Two factors which could operate to limit the amount of self-fertilisation have been investigated.

\section{(i) The need for tripping}

Large increases in seed setting due to tripping have been reported by Reisch (1952), Drayner (1956) and Rowlands (1958). Results of experiments done in this present work confirm this effect of tripping on the efficiency of self-fertilisation.

Two groups of winter bean plants were scored for self-fertility in a bee-proof greenhouse. One group was left untripped and on the other the flowers were tripped manually by depressing the keel petals. The mean fertility of 4.8 pods per I oo untripped flowers was significantly less, at the 5 per cent. point, than the mean fertility of 9.6 pods per Ioo tripped flowers.

In a second experiment on a group of 28 spring Tic bean plants, the inflorescences were treated in pairs, the flowers reduced to equal numbers, usually 3 or 4 at each, and those at each node were either tripped or left untripped: $4 \mathrm{I}$ pods and $8 \mathrm{I}$ seeds resulted from tripping 672 flowers, whereas only one pod and one seed were set from the 647 flowers which were left untripped.

It is clear from these results that self-fertilisation is infrequent in the absence of tripping and occurs quite readily if the flowers are tripped. The only visible change brought about by the tripping process is the rupture of stigmatic papillæ and so the difference in self-fertilisation would seem to be connected, in a way not understood, but similar to that in lucerne (Armstrong and White, I935) with the condition of the stigmatic surface and the germination of self pollen. Whatever the precise effect of tripping on the pollen-stigma reaction the tripping requirement has important genetical consequences, for it serves to prevent complete self-fertilisation and to hold back self pollen until the arrival of foreign pollen, brought by the tripping insect.

\section{(ii) Spontaneous self-fertility}

This need for tripping does not, however, occur in all population plants. Observations made during the course of this work showed that while some plants set no seed in the absence of tripping, others 
set seed quite readily when untripped, i.e. were spontaneously selffertile, a term derived from Drayner (1956) to describe this ability to set seed without disturbance of the flower, and synonymous with the term autofertility which she uses later (Drayner, 1959). In both papers she shows that groups of untripped crossbred plants showed a marked increase in seed setting over untripped inbreds. Larkin and Graumann (1954) distinguished between lines of lucerne on their frequency of self-tripping and while self-tripping has not been observed in $V . f a b a$ it was thought possible that genetic variability for this

TABLE 5

The effects of selection for and against spontaneous self-fertility.

Fertility expressed as pods/100 flowers treated

\begin{tabular}{|c|c|c|c|c|c|c|c|}
\hline \multicolumn{2}{|c|}{ I 954} & \multicolumn{3}{|c|}{ I 955} & \multicolumn{3}{|c|}{ I $95^{6}$} \\
\hline Parents & Untripped & Progenies & Untripped & Tripped & Selections & Untripped & Tripped \\
\hline S. 45 & $6 \cdot 5$ & $\begin{array}{c}\mathrm{S} .45 / 1 \\
/ 2 * \\
/ 3 \\
/ 5\end{array}$ & $\begin{array}{c}30 \cdot 0 \\
70 \cdot 0 \\
0 \\
27 \cdot 7\end{array}$ & $\begin{array}{l}44 \cdot 4 \\
53 \cdot 8 \\
66 \cdot 6 \\
31 \cdot 6\end{array}$ & $\begin{array}{r}\mathrm{S} .45 / 2 / \mathrm{I} \\
/ 2 \\
13 \\
14\end{array}$ & $\begin{array}{r}35 \cdot 7 \\
50 \cdot 0 \\
6 \cdot 7 \\
75 \cdot 0\end{array}$ & $\begin{array}{l}42 \cdot 9 \\
75 \cdot 0 \\
30 \cdot 8 \\
55 \cdot 6\end{array}$ \\
\hline S.12 & $45^{\circ} \mathrm{o}$ & $\begin{array}{c}\mathrm{S} . \mathrm{I} 2 / \mathrm{I} \\
/ 2 \\
/ 4 \\
15 \\
16\end{array} *$ & $\begin{array}{l}35 \cdot 3 \\
28 \cdot 6 \\
37 \cdot 5 \\
18 \cdot 8 \\
33 \cdot 3\end{array}$ & $\begin{array}{r}40 \cdot 0 \\
33 \cdot 3 \\
28 \cdot 6 \\
100 \cdot 0 \\
57 \cdot 1\end{array}$ & $\begin{array}{r}\mathrm{S} . \mathrm{I} 2 / 4 / \mathrm{I} \\
/ 2 \\
13 \\
14\end{array}$ & $\begin{array}{r}5.3 \\
\text { I0.0 } \\
\text { I } 5.8 \\
27.8\end{array}$ & $\begin{array}{l}50 \cdot 0 \\
43 \cdot 8 \\
52 \cdot 6 \\
58 \cdot 3\end{array}$ \\
\hline S.7I & 25.9 & $\begin{array}{c}\mathrm{S} .71 / \mathrm{I} \\
/ 2 * \\
/ 3 \\
/ 4\end{array}$ & $\begin{array}{l}5 \cdot 4 \\
0 \\
6 \cdot 3 \\
0\end{array}$ & $\begin{array}{r}47 \cdot 2 \\
9 \cdot 1 \\
18 \cdot 8 \\
39 \cdot 4\end{array}$ & $\begin{array}{r}\mathrm{S} .7 \mathrm{I} / 2 / \mathrm{I} \\
/ 2 \\
13 \\
14\end{array}$ & $\begin{array}{l}0 \\
0 \\
0 \\
0\end{array}$ & $\begin{array}{l}58 \cdot 8 \\
33 \cdot 3 \\
3 \mathrm{I} \cdot 6 \\
3 \mathrm{I} \cdot 3\end{array}$ \\
\hline
\end{tabular}

* Plants selected as parents.

character of selfing without tripping might be present within populations and between lines.

In 1955 , io lines (4-6 plants per line) de rived from spontaneously self-fertile plants which had been selfed for one generation since open pollination, were compared for spontaneous selfing ability. Alternate inflorescences were tripped as a control.

For tripped flowers there were no significant differences between any lines. For the untripped flowers 2 lines, namely S.I2 and S.45 showed significantly greater fertility than 4 other lines. An attempt was made to select for and against this character, and the results of three line selections are given in table 5 .

The data for line S. 45 show that it is possible successfully to select for a greater degree of spontaneous self-fertility, while line S.7 I shows how rapidly this character may be lost. In the case of line S.I2, 
spontaneous self-fertility appears to be declining despite selection in the opposite direction.

The selected inbreds S.45/2 and S.I2/4 together with four lines which had been twice crossbred and five unselected inbred lines, were incorporated in a trial to compare self-fertility with and without tripping between these three groups. All plants were hand tripped at alternate inflorescences, and the results are given in table 6. There were no significant differences in fertility between the three groups

\section{TABLE 6}

Self-fertility, without tripping, of two groups of inbred lines and one group of double crossbreds 1956. Fertility expressed as mean seeds per flower treated. Data transformed to $\sqrt{x+0 \cdot 5}$

\begin{tabular}{|c|c|c|c|c|c|c|c|c|c|c|}
\hline \multirow[b]{2}{*}{$\begin{array}{l}\text { Progeny } \\
\text { ref. no. }\end{array}$} & \multicolumn{4}{|c|}{ Unselected inbred lines } & \multicolumn{2}{|c|}{$\begin{array}{l}\text { Inbred lines } \\
\text { selected for } \\
\text { spontaneous } \\
\text { self-fertility }\end{array}$} & \multicolumn{4}{|c|}{$\begin{array}{l}\text { Double crossbreds } \\
\text { (i.e. population plants } \\
\text { twice crossbred) }\end{array}$} \\
\hline & $\begin{array}{c}\mathrm{T} \cdot 94 / 8 \\
(2)^{*}\end{array}$ & $\begin{array}{c}\mathrm{T} .88 / 3 \\
(2)\end{array}$ & $\mathrm{SF} \cdot 7 / 2 / \mathrm{I}$ & $\underset{(\mathrm{I})}{\mathrm{A}_{5} / 6}$ & $\begin{array}{c}\text { S. } 45 / 2 \\
(2)\end{array}$ & $\begin{array}{c}\text { S. } 12 / 4 \\
(2)\end{array}$ & I & 2 & 3 & 4 \\
\hline I & $0.7 \mathrm{I}$ & 0.74 & 0.71 & 0.71 & I. IO & 0.74 & $0 \cdot 74$ & $\mathrm{I} \cdot \mathrm{I} 2$ & $0 \cdot 76$ & $0.7 \mathrm{I}$ \\
\hline 2 & $0 \cdot 71$ & $0.7 \mathrm{I}$ & 0.71 & $0 \cdot 74$ & I $\cdot 26$ & 0.84 & 0.97 & $\mathrm{I} \cdot \mathrm{O} 3$ & $\mathrm{I} \cdot \mathrm{O} 3$ & $0 \cdot 76$ \\
\hline 3 & 0.74 & 0.74 & 0.71 & $0.7 \mathrm{I}$ & 0.75 & 0.84 & 0.86 & 0.79 & $\mathrm{I} \cdot 23$ & $I \cdot I_{2}$ \\
\hline 4 & $\cdots$ & $0 \cdot 77$ & $0 \cdot 71$ & $0 \cdot 71$ & $I \cdot 46$ & $0 \cdot 88$ & 0.71 & $1 \cdot 20$ & $I \cdot 26$ & $\ldots$ \\
\hline $\begin{array}{l}\text { Group } \\
\text { means }\end{array}$ & \multicolumn{4}{|c|}{ (A) 0.72} & \multicolumn{2}{|c|}{ (B) $0.9^{8}$} & \multicolumn{4}{|c|}{ (C) 0.95} \\
\hline
\end{tabular}

Min. significant difference at I per cent. point between group means by " $q$ " test $=0$. I 8

Difference $\mathrm{B}-\mathrm{A}=0 \cdot 26 * *$

$$
\begin{aligned}
& \mathrm{C}-\mathrm{A}=0.23^{* *} \\
& \mathrm{~B}-\mathrm{C}=0.03 \text { N.S. }
\end{aligned}
$$

Differences between lines within groups, non-significant.

\footnotetext{
* Figures in parentheses refer to number of generations inbred.
}

when the flowers were tripped, but the values for spontaneous selffertility from the untripped flowers varied considerably. The group means of the selected inbreds and the crossbreds, while not differing from each other, are significantly higher than the group mean of the unselected inbreds. This is a clear indication of the greater ability of these two groups to self-fertilise in the absence of tripping.

These results in tables 5 and 6 are such that two explanations of this spontaneous self-fertility are possible:

(a) Heterozygosity. The twice crossbred plants will be heterozygous for more genes than the unselected inbred lines which have been selfed for two generations. This immediately suggests an association between heterozygosity and spontaneous self-fertility. 
This conclusion is in agreement with Drayner's (1956) observation that single crossbreds were more spontaneously self-fertile than inbreds and plants from commercial stocks. Furthermore the rapid decline in spontaneous self-fertility of line S.7r (table 8) after one generation of selfing can be explained by assuming that the high value for the original S.7I parent was due to heterozygosity.

Further evidence of the association between spontaneous selffertility and heterozygosity was obtained by allowing two inbred lines, and $F_{1}$ derived from crossing them, to set seed in the absence of tripping. All flowers produced by each of the eight plants in each group were left untripped.

The results given in table 7 illustrate the very marked superiority of the hybrids in spontaneous self-fertility. It is worth pointing out

TABLE 7

Spontaneous self-fertility of 2 inbred lines and of the $F_{1}$ hybrid between them

\begin{tabular}{|c|c|c|c|}
\hline & $\begin{array}{c}\text { Line } A \\
\text { Inbred } 2 \text { generations }\end{array}$ & $\begin{array}{c}\text { Line } B \\
\text { Inbred } 2 \text { generations }\end{array}$ & $\begin{array}{l}\text { Hybrid } F_{1} \text { 's from } \\
A \times B\end{array}$ \\
\hline $\begin{array}{l}\text { Total pods } \\
\text { Mean pods/plant }\end{array}$ & $\stackrel{29}{3 \cdot 625}$ & $\begin{array}{l}3 \\
o \cdot 375\end{array}$ & $\begin{array}{l}\text { II } 4 \\
\quad 14 \cdot 250\end{array}$ \\
\hline $\begin{array}{l}\text { Total seeds } \\
\text { Mean seeds/plant }\end{array}$ & $\begin{array}{l}45 \\
5 \cdot 625\end{array}$ & $\begin{array}{l}7 \\
0 \cdot 875\end{array}$ & $\begin{array}{r}213 \\
26 \cdot 625\end{array}$ \\
\hline Mean seeds/pod & I. 55 & $2 \cdot 33$ & I $\cdot 868$ \\
\hline
\end{tabular}

that the increased yield of the hybrids is not simply a general manifestation of greater vigour, although they probably would have yielded more than the inbreds under conditions of open pollination, nor to an increased number of seeds per pod since this value is below that for one of the inbreds, but rather to the ability of the hybrids to achieve fertilisation on more flowers in the absence of tripping.

(b) Specific genes. The results given in table 5 of self-fertilisation and selection in line S.45, and to a lesser extent in line S.r2, are a strong indication that the inbreeding and selection have served to concentrate specific genes controlling this character. The intensification of its expression from a low value of 6.5 in the initial selection to values of $5^{\circ} \cdot 0$ and $75^{\circ} \mathrm{o}$ two generations later strongly supports this view.

\section{(iii) Differential pollen tube growth}

It has recently been suggested by Rowlands (1958) that self and foreign pollen germinate on the stigma, and grow down the style 
at different rates, and that this differentiation between the two types of pollen is initiated by the stigmatic exudate following tripping. In his experiments he germinated pollen grains in culture solutions to some of which he added a stylar extract. Presence of this extract resulted in an enhanced germination percentage and rate of growth of unrelated pollen. In the present work we have endeavoured to detect the operation of such a mechanism in vivo, by studying the amount of seed setting due to self and foreign pollen.

TABLE 8

Per cent. cross fertilisation at different ovule positions within the pod

\begin{tabular}{|c|c|c|c|c|c|c|c|}
\hline & \multirow{2}{*}{\multicolumn{3}{|c|}{$\begin{array}{l}\text { Hilum colour } \\
\text { of progeny }\end{array}$}} & \multicolumn{4}{|c|}{ Position in pod } \\
\hline & & & & Style & 2 & 3 & Stem \\
\hline \multirow[t]{2}{*}{ I. } & $\begin{array}{l}\text { Golourless } \\
\text { Black . }\end{array}$ & $\dot{.}$ & $\dot{.}$ & $\begin{array}{l}80 \\
\text { I I }\end{array}$ & $\begin{array}{l}75 \\
\text { I } 2\end{array}$ & $\begin{array}{l}79 \\
\text { I I }\end{array}$ & $\begin{array}{r}62 \\
9\end{array}$ \\
\hline & Per cent. B & & . & I $2 \cdot I$ & $13 \cdot 8$ & $12 \cdot 2$ & $12 \cdot 7$ \\
\hline \multirow[t]{2}{*}{2.} & $\begin{array}{l}\text { Colourless } \\
\text { Black . }\end{array}$ & . & : & $\begin{array}{l}21 \\
16\end{array}$ & $\begin{array}{l}25 \\
13\end{array}$ & $\begin{array}{l}21 \\
17\end{array}$ & $\begin{array}{l}\text { I3 } \\
\text { I4 }\end{array}$ \\
\hline & Per cent. $\mathrm{B}$ & & - & $43 \cdot 3$ & $34 \cdot 2$ & $44 \cdot 7$ & $5^{I} \cdot 9$ \\
\hline \multirow[t]{2}{*}{3.} & $\begin{array}{l}\text { Colourless } \\
\text { Black . }\end{array}$ & $\dot{.}$ & $\dot{.}$ & $\begin{array}{l}83 \\
43\end{array}$ & $\begin{array}{l}80 \\
46\end{array}$ & $\begin{array}{l}78 \\
5^{\circ}\end{array}$ & $\begin{array}{l}62 \\
22\end{array}$ \\
\hline & Per cent. B & & . & $34^{\cdot} \cdot$ & $36 \cdot 5$ & $39^{\circ} \mathrm{o}$ & $26 \cdot 2$ \\
\hline \multirow[t]{2}{*}{4} & $\begin{array}{l}\text { Colourless } \\
\text { Black • }\end{array}$ & $\dot{.}$ & $\dot{.}$ & $\begin{array}{r}22 \mathrm{I} \\
20\end{array}$ & $\begin{array}{r}224 \\
15\end{array}$ & $\begin{array}{r}215 \\
20\end{array}$ & $\begin{array}{r}79 \\
9\end{array}$ \\
\hline & Per cent. B & $\mathrm{ck}$ & - & $8 \cdot 3$ & $6 \cdot 3$ & $8 \cdot 5$ & $10 \cdot 2$ \\
\hline
\end{tabular}

Correns (I92I) was able to differentiate between the growth of two types of pollen in Melandrium by cutting off the style at certain time intervals after pollination. This method was applied to a group of 12 winter bean plants in 1955. The flowers were emasculated and one group was pollinated with self pollen, the other with foreign pollen. The styles of some flowers in each group were cut at the bend at half hour intervals after pollination.

The results showed that the critical time for both self and foreign pollen tubes was between 5 and $5 \frac{1}{2}$ hours after pollination, since both types of pollen tube passed the cutting level during this time interval. These results are similar to those of Drayner (1959), and while they 
indicate that foreign pollen was at no advantage in this material there are also two other possibilities:

(I) The technique was perhaps not sufficiently refined to discriminate between two slightly different growth rates, or

(2) The differentiation occurs in tissues nearer the base of the style, i.e. beyond the point of cutting.

In order to test these possibilities it was decided to shift the site of assessment to the seed itself. If the "foreign " pollen tubes enjoyed a growth rate advantage at any point between the stigma and the ovule, then the ovule nearest the stigma might be fertilised more frequently by a "foreign" gamete than by a "self" gamete.

Pods were taken from colourless hilum plants (recessive testers) drawn at random from four natural populations of winter and spring beans. The seeds were then identified according to their position in the pod, sown, and their progeny scored for hilum colour. Only fertilisations due to foreign gametes carrying the black hilum allele yield information and a higher frequency of black hilum progeny are expected from the stylar end of the pod than from the stem end if foreign pollen enjoys a slightly faster growth rate.

The data for hilum colour in the progeny are given in table 8 . The percentages of black hilum progeny indicate the same extent of cross-fertilisation whether the ovules were near to, or distant from, the style.

Further, if self pollen tubes were slow growing, it is possible that in the absence of foreign pollen some ovules would remain unfertilised. However, it was noted over a number of greenhouse experiments that as many seeds per pod were set from self- as from cross-pollinations.

These results are supported by simultaneous work of Drayner (I956) who found that mixed pollination with self and foreign pollen gave no difference in seed setting when compared with that due to self pollen, on crossbreds, plants from commercial seed and second generation inbreds. Foreign pollen was superior only on fourth generation inbreds.

Apart therefore from Rowlands' (I 958) data from cultures the evidence points to the absence of any differential pollen tube growth.

\section{DISCUSSION}

The data on natural cross fertilisation confirm the findings of earlier workers, that it occurs to an extent intermediate between complete self- and cross-fertilisation. The I953 estimates for the Norfolk and Cockle Park populations are similar to those obtained in Britain by Fyfe and Bailey (I95I), Fyfe (1954), and Griffiths and Rowlands (unpublished). On the other hand, the I954 estimates for both the winter and the spring field beans show a very marked increase over those for I953. This difference may be attributed to one or more different causes: 
(I) The sample of plants taken from the 1954 winter bean population was not at random but was biased with respect to their previous breeding history. In order to simplify the scoring of the I 955 material, colourless hilum seeds were sown from the progeny of the I 953 homozygous recessives only (see fig. I). That is, no progeny were sown from known crossbred parents and hence there was discrimination against plants likely to show a high frequency of self-fertilisation (see spontaneous self-fertility below) leading to an enhanced estimate of cross fertilisation. The remarkable genetic purity of the spring bean varieties with respect to testa colour suggests that discrimination had operated in this material also against the presence of spontaneously self-fertile plants. This genetic uniformity implies selection and isolation of the varietal stocks, factors which would lead through a reduction in heterozygosity to a higher frequency of cross-fertilisation.

(2) The data presented in table 4 demonstrate the effect of spacing on frequency of cross fertilisation. The nature of this effect is not clear but is possibly connected with attractiveness of the crop to the bee. Since the I954 plants were widely spaced and intersected by numerous paths, a part of the 1954-55 difference could be attributed to this cause. It would be interesting to know whether there has been a general decline in the frequency of cross fertilisation with the change in practice from growing beans in widely spaced drills to the now frequent method of close drilling, when the crop at flowering time is quite dense.

(3) The estimates of cross fertilisation for the broad bean varieties are much lower than those for the field beans grown in the same year, and under the same conditions. This we attribute to a preference of the bees for the field bean varieties with their smaller flowers, shorter corolla tubes and more accessible nectar.

It is possible therefore, to account for the variability in the estimates of natural crossing, not only in our own data, but also in those previously reported in the literature. Biased sampling, exceptionally wide spacing of plants, size of flowers and climate (Picard, I953) could either singly or in combination have been responsible for the variation of 5 to 79 per cent. between previous estimates. Therefore of those reported here only the I 953 winter bean figures relating to natural field populations can be taken as a measure of the frequency of cross fertilisation under farm conditions. The grouping of these estimates around 30 to 40 per cent. is significant when considered in relation to the breeding system of the species.

The need for tripping and the magnitude of its effects on selffertilisation in isolated population plants have been clearly demonstrated. The process would seem to affect the receptivity of the stigma to self pollen possibly through the rupture of stigmatic papillæ as in lucerne. The tripping requirement delays the germination of self pollen on the stigma until the arrival of foreign pollen. Hence cross fertilisation is possible, but its frequency will depend on the relative 
growth rates of self and foreign pollen tubes in the tissues of stigma and style. Rowlands' (I958) work with pollen cultures suggests that foreign pollen enjoys an enhanced rate of germination and growth, but attempts to detect this process in the stylar decapitation experiments and to measure its consequences by scoring the frequency of cross fertilisation at different positions in the pod (table 8), give good but not conclusive evidence that if differential pollen tube growth does occur, then the difference must be very slight. It may in fact be limited to the fertilisation of inbred plants whose own pollen is of low vigour and viability due to abnormal meiosis following inbreeding.

It is concluded therefore from the balance of the evidence available that the need for tripping coupled with bee visitation and the arrival of foreign pollen enables self and foreign pollen to germinate together, and, in the absence of differential pollen tube growth rates, to effect an equal number of fertilisations.

However, not all plants need to have their flowers tripped to set seed. Some appear to be spontaneously self-fertile and from the evidence presented in tables 5,6 and 7 , it would seem that spontaneous self-fertility can be due to two different genetic causes:

(i) Heterozygosity per se.

(ii) Specific genes.

(i) Heterozygosity and spontaneous self-fertility. Spontaneous selffertility due to this cause may be regarded as a particular or specific expression of hybrid vigour, and may reflect the ability of the stigma to stimulate the germination of self pollen without the usual prerequisite of tripping. Drayner (1956) has pointed out that this attribute would be of particular value to the species in years of low bee activity, since it confers reproductive independence of bee activity on that proportion of the population whose progeny are least likely to be adversely affected by the consequences of selfing.

Since pollen is shed before the flower opens we make the assumption that self pollen germinates before visitation and therefore that all heterozygotes capable of spontaneous self-fertilisation do selffertilise. There is the possibility, however, that this faculty may only be utilised if no visitation occurs, a view held by Drayner (r959). The difference is in the time at which spontaneous self-fertilisation occurs but the consequences to the species are likely to be different. In the first case the number of inbreds produced by spontaneous self-fertilisation would be mainly dependent on the number of spontaneous self-fertile parents in the population. In the second case it would depend primarily on the level of bee activity. With an adequate population of the two useful bumble bees $B$. agrorum and $B$. hortorum one could expect equal numbers of inbred and crossbred progeny in a population.

In fact, of the British estimates of cross fertilisation which do reach 
50 per cent., Fyfe and Bailey's ( I 95 I) figure of $48 \cdot 5$ per cent. has been shown by them to be due to exceptional winter killing of inbreds in their material, leading to an unusually high estimate of crossbreds, while the I 954 winter and spring bean estimates reported here are of doubtful value for the reasons discussed above. Thus there is difficulty in reconciling the above expectation of $5^{\circ}$ per cent. crossing with the evidence of only 30 per cent. unless one assumes also that bee activity is inadequate and as a result spontaneous self-fertility occurs. There is no evidence to support this assumption so far as we are aware, and it appears to be an unlikely possibility, for the plant is buffered against variations in bee activity by the large numbers of flowers produced both serially in time and at successive nodes, in relation to the number of mature pods which it can support. We conclude therefore, that highly heterozygous crossbreds regularly self-fertilise and yield a proportion of inbred progeny to the following generations.

It is tempting to speculate that the two breeding mechanisms discussed above, i.e. spontaneous self-fertility and the need for tripping which operate in different individuals, and which differ in their consequences, may be responsible for the frequency of estimates of $30-$ 40 per cent. crossing in natural populations. It is possible that $30-40$ per cent. crossing may represent an equilibrium point in a balanced breeding system where the crossbred one-third self-fertilise through spontaneous self-fertility and the inbreds, following insect tripping, produce inbreds and crossbreds in equal proportions. Such a system would be self perpetuating, yielding one-third crossbreds and twothirds inbreds in each generation.

(ii) Specific genes for spontaneous self-fertility. The data in table 5 clearly demonstrate the possibility of selecting for, and of fixing, this character in a line. Rowlands (1958) has discussed the value of inbred lines to agriculture and the adoption of this aim as a long-term breeding policy. The formidable problems of infertility due to abnormal meiosis consequent on inbreeding, and of general inbreeding depression remain, but these data on spontaneous self-fertility at least go part of the way in showing that such a shift in the breeding system (already complete in the pea) may be a practicable breeding objective.

\section{SUMMARY}

I. Estimates of natural cross fertilisation in winter field beans in I953 gave values of 29.5 and 34.8 per cent. for Norfolk and Cockle Park material respectively. In I954 at Cockle Park the estimates were: for winter beans 69.8 per cent., for spring field beans 60.5 per cent. and for broad beans $3^{2} \cdot 5,35^{\cdot} \mathrm{I}$ and $4 \mathrm{I} \cdot 2$ per cent. cross fertilisation.

2. Dissection of flowers shows that stigmatic papillæ are ruptured by the tripping process and that pollen is present on the stigma and in the keel for 24 hours before the flower is open and ready for bee visitation. 
3. As the above estimates show, this self-pollination does not lead to complete self-fertilisation. Large increases in seed setting due to self-fertilisation follow tripping. It is inferred that tripping, through the rupture of the stigmatic surface, renders the stigma suitable for pollen germination, and the need for tripping ensures that, with the coincident arrival of foreign pollen, both self and foreign pollen may germinate together.

4. The frequencies of self- and cross-fertilisation in tripped flowers will depend on the relative growth rates of self and foreign pollen tubes down the style. Experiments failed to reveal any differential growth rates in this material and it is concluded that tripped, i.e. visited flowers, yield equal numbers of selfed and crossed progeny.

5. Not all population plants need to be tripped in order to set seed. Some have the ability to self-fertilise quite readily when untripped, i.e. are spontaneously self-fertile.

6. Spontaneous self-fertility is a property of crossbred plants and of certain inbred individuals and lines. It appears to have two causes (i) heterozygosity in population plants, and (ii) specific genes in inbred lines.

7. It is suggested that the breeding behaviour of a plant depends on its origin. Crossbreds will tend to self through spontaneous selffertility while inbreds which require to be tripped will yield both inbred and crossbred progeny.

\section{REFERENCES}

ARMSTRONG, J. M., AND White, w. J. 1935. Factors influencing seed setting in alfalfa. 7. Agric. Sci., 25, I6 I-I 79 .

CORRENS, C. I921. Zweite fortsetzung der Versuche zur experimentellen Verschiebung des Geschlechtsverhältnisses. Sitzungsber D. Preuss. Akad. d. Wiss., $18,330-354$.

CREBERT, H. I93 I. Beobachtungen bie der Kreusungszuchtung mit der Pferdebohne. Zuchter, 3, 360-364.

DRAYNER, J. M. I956. Regulation of outbreeding in field beans (Vicia faba L.). Nature, ${ } 76,489-490$.

DRAYNER, J. M. I 959 . Self- and cross-fertility in field beans (Vicia faba LINN.). 7. Agric. Sci., 53, 385-403.

ERITH, ADELA G. I930. Inheritance of colour, size and form of seeds and of flower colour in Vicia faba. Genetica, 12, 477-5 Io.

FYFE, J. L., AND BAILEY, N. T. J. I $95 \mathrm{I}$. Plant breeding studies in leguminous forage crops. I. Natural crossbreeding in winter beans. F. Agric. Sci., 41, 37 1-378.

FYFE, J. L. I954. Plant breeding studies in leguminous forage crops. II. Further observations on natural crossbreeding in winter beans. F. Agric. Sci., 45, $14 \mathrm{I}-\mathrm{I} 47$.

GRIFFITHS, D. J., AND ROWLANDS, D. G. Personal communication.

LARKIN, R. A., AND GRAUMANN, H. O. I954. Anatomical structure of the alfalfa flower and explanation of the tripping mechanism. Bot. Gazette, ${ }_{11} 6,4^{0}$.

PICARD, J. 1953. Recherches sur la feverole. Annales de l'Amelioration des plantes, 3, 57-106.

REISCH, w. 1952. Variabilität studien an Vicia faba L. Z. f. Acker und Pflanznb., $94,3,28 \mathrm{I}-306$. 
ROWLANDS, D. G. 1958. The nature of the breeding system in the field bean ( $V$. $f a b a \mathrm{~L})$ and its relationship to breeding for yield. Heredity, I2, I 13-125.

shen, L. y. 1947. A study of natural crossing in Vicia faba. 7. Agric. Ass. China, No, 185,8 .

sIRKs, M. J. I923. Die Verschiebung genotypischer Verhaltniszahlen innerhalb Populationen lant mathematischer Berechnung und experimenteller Prufung. Med. LandbHoogesch. Wageningen., 26, $40 \mathrm{pp}$.

SIRks, M. J. I931. Beitrage zu einer Genotypischen Analyse der Ackerbohne Vicia faba L. Genetica, I3, 209-631. 